\title{
Correction: Early academic achievement in children with isolated clefts: a population-based study in England
}

Fitzsimons KJ, Copley LP, Setakis E, et al. Early academic achievement in children with isolated clefts: a population-based study in England. Arch Dis Child 2018;103:356-62.

The authors have noticed that during the production process some errors were introduced into table 3. Many of the 95\% confidence interval ranges should be negative. We would like to apologise for these errors and the corrected table 3 is below. Also, in the abstract, a couple of numbers and one word need changing within the Results section. The following sentence should read: 'Academic achievement was significantly below national average for all six assessed areas with z-scores ranging from -0.24 (95\% CI -0.32 to 0.16 ) for knowledge of world to $-0.32(-0.42$ to -0.23$)$ for physical development.'

Table 3 Results of multivariable linear regression analyses of effect of cleft type on the z-scores for the six assessed areas of learning of the early years foundational stage profile (difference compared with $\mathrm{Cl}$ with $95 \% \mathrm{Cl}$ )

\begin{tabular}{|c|c|c|c|c|c|c|}
\hline Characteristic & $\begin{array}{l}\text { Personal, social } \\
\text { and emotional } \\
\text { development }\end{array}$ & $\begin{array}{l}\text { Communication, } \\
\text { language and } \\
\text { literacy }\end{array}$ & $\begin{array}{l}\text { Mathematical } \\
\text { development }\end{array}$ & $\begin{array}{l}\text { Knowledge and } \\
\text { understanding of } \\
\text { the world }\end{array}$ & $\begin{array}{l}\text { Physical } \\
\text { development }\end{array}$ & $\begin{array}{l}\text { Creative } \\
\text { development }\end{array}$ \\
\hline \multicolumn{7}{|l|}{ Cleft type } \\
\hline $\mathrm{CL}$ & Ref & Ref & Ref & Ref & Ref & Ref \\
\hline $\mathrm{CP}$ & $\begin{array}{l}-0.25 \\
(-0.35 \text { to }-0.15)\end{array}$ & $\begin{array}{l}-0.28 \\
(-0.38 \text { to }-0.19)\end{array}$ & $\begin{array}{l}-0.27 \\
(-0.37 \text { to }-0.17)\end{array}$ & $\begin{array}{l}-0.31 \\
(-0.41 \text { to }-0.20)\end{array}$ & $\begin{array}{l}-0.32 \\
(-0.44 \text { to }-0.20)\end{array}$ & $\begin{array}{l}-0.28 \\
(-0.39 \text { to }-0.18)\end{array}$ \\
\hline UCLP & $\begin{array}{l}-0.11 \\
(-0.22 \text { to }-0.01)\end{array}$ & $\begin{array}{l}-0.19 \\
(-0.28 \text { to }-0.09)\end{array}$ & $\begin{array}{l}-0.15 \\
(-0.26 \text { to }-0.05)\end{array}$ & $\begin{array}{l}-0.18 \\
(-0.29 \text { to }-0.07)\end{array}$ & $\begin{array}{l}-0.14 \\
(-0.26 \text { to }-0.01)\end{array}$ & $\begin{array}{l}-0.15 \\
(-0.26 \text { to }-0.03)\end{array}$ \\
\hline BCLP & $\begin{array}{l}-0.19 \\
(-0.33 \text { to }-0.05)\end{array}$ & $\begin{array}{l}-0.30 \\
(-0.43 \text { to }-0.17)\end{array}$ & $\begin{array}{l}-0.19 \\
(-0.33 \text { to }-0.04)\end{array}$ & $\begin{array}{l}-0.25 \\
(-0.40 \text { to }-0.10)\end{array}$ & $\begin{array}{l}-0.37 \\
(-0.54 \text { to }-0.21)\end{array}$ & $\begin{array}{l}-0.25 \\
(-0.40 \text { to }-0.10)\end{array}$ \\
\hline \multicolumn{7}{|l|}{ IDACI } \\
\hline (most deprived) 1 & Ref & Ref & Ref & Ref & Ref & Ref \\
\hline 2 & $\begin{array}{l}0.09 \\
(-0.02 \text { to } 0.21)\end{array}$ & $\begin{array}{l}0.11 \\
(0.00 \text { to } 0.22)\end{array}$ & $\begin{array}{l}0.18 \\
(0.07 \text { to } 0.30)\end{array}$ & $\begin{array}{l}0.23 \\
(0.11 \text { to } 0.35)\end{array}$ & $\begin{array}{l}0.13 \\
(-0.01 \text { to } 0.27)\end{array}$ & $\begin{array}{l}0.16 \\
(0.03 \text { to } 0.28)\end{array}$ \\
\hline 3 & $\begin{array}{l}0.25 \\
(0.13 \text { to } 0.37)\end{array}$ & $\begin{array}{l}0.32 \\
(0.21 \text { to } 0.44)\end{array}$ & $\begin{array}{l}0.40 \\
(0.28 \text { to } 0.53)\end{array}$ & $\begin{array}{l}0.45 \\
(0.32 \text { to } 0.58)\end{array}$ & $\begin{array}{l}0.30 \\
(0.15 \text { to } 0.44)\end{array}$ & $\begin{array}{l}0.37 \\
(0.24 \text { to } 0.50)\end{array}$ \\
\hline 4 & $\begin{array}{l}0.41 \\
(0.29 \text { to } 0.54)\end{array}$ & $\begin{array}{l}0.48 \\
(0.36 \text { to } 0.59)\end{array}$ & $\begin{array}{l}0.55 \\
(0.42 \text { to } 0.68)\end{array}$ & $\begin{array}{l}0.54 \\
(0.40 \text { to } 0.67)\end{array}$ & $\begin{array}{l}0.43 \\
(0.28 \text { to } 0.58)\end{array}$ & $\begin{array}{l}0.50 \\
(0.36 \text { to } 0.63)\end{array}$ \\
\hline (least deprived) 5 & $\begin{array}{l}0.51 \\
(0.37 \text { to } 0.64)\end{array}$ & $\begin{array}{l}0.58 \\
(0.46 \text { to } 0.71)\end{array}$ & $\begin{array}{l}0.71 \\
(0.57 \text { to } 0.84)\end{array}$ & $\begin{array}{l}0.69 \\
(0.55 \text { to } 0.83)\end{array}$ & $\begin{array}{l}0.53 \\
(0.37 \text { to } 0.69)\end{array}$ & $\begin{array}{l}0.59 \\
(0.45 \text { to } 0.74)\end{array}$ \\
\hline \multicolumn{7}{|l|}{ Free school meals } \\
\hline No & Ref & Ref & Ref & Ref & Ref & Ref \\
\hline Yes & $\begin{array}{l}-0.38 \\
(-0.48 \text { to }-0.27)\end{array}$ & $\begin{array}{l}-0.47 \\
(-0.57 \text { to }-0.38)\end{array}$ & $\begin{array}{l}-0.41 \\
(-0.52 \text { to }-0.31)\end{array}$ & $\begin{array}{l}-0.36 \\
(-0.47 \text { to }-0.25)\end{array}$ & $\begin{array}{l}-0.34 \\
(-0.46 \text { to }-0.21)\end{array}$ & $\begin{array}{l}-0.35 \\
(-0.46 \text { to }-0.24)\end{array}$ \\
\hline \multicolumn{7}{|l|}{ Ethnicity } \\
\hline White & Ref & Ref & Ref & Ref & Ref & Ref \\
\hline Other & $\begin{array}{l}-0.07 \\
(-0.17 \text { to } 0.03)\end{array}$ & $\begin{array}{l}-0.08 \\
(-0.18 \text { to } 0.01)\end{array}$ & $\begin{array}{l}-0.14 \\
(-0.24 \text { to }-0.03)\end{array}$ & $\begin{array}{l}-0.14 \\
(-0.25 \text { to }-0.03)\end{array}$ & $\begin{array}{l}-0.05 \\
(-0.17 \text { to } 0.07)\end{array}$ & $\begin{array}{l}-0.08 \\
(-0.19 \text { to } 0.03)\end{array}$ \\
\hline \multicolumn{7}{|l|}{ Sex } \\
\hline Girls & Ref & Ref & Ref & Ref & Ref & Ref \\
\hline Boys & $\begin{array}{l}-0.36 \\
(-0.44 \text { to }-0.28)\end{array}$ & $\begin{array}{l}-0.33 \\
(-0.41 \text { to }-0.26)\end{array}$ & $\begin{array}{l}-0.18 \\
(-0.26 \text { to }-0.10)\end{array}$ & $\begin{array}{l}-0.15 \\
(-0.24 \text { to }-0.07)\end{array}$ & $\begin{array}{l}-0.42 \\
(-0.52 \text { to }-0.32)\end{array}$ & $\begin{array}{l}-0.58 \\
(-0.66 \text { to }-0.49)\end{array}$ \\
\hline R-Squared $¥$ & 0.097 & 0.14 & 0.118 & 0.1 & 0.079 & 0.123 \\
\hline
\end{tabular}

Open access This is an open access article distributed in accordance with the Creative Commons Attribution Non Commercial (CC BY-NC 4.0) license, which permits others to distribute, remix, adapt, build upon this work noncommercially, and license their derivative works on different terms, provided the original work is properly cited, appropriate 
credit is given, any changes made indicated, and the use is non-commercial. See: http://creativecommons.org/licenses/by-nc/ 4.0\%.

(c) Author(s) (or their employer(s)) 2021. Re-use permitted under CC BY-NC. No commercial re-use. See rights and permissions. Published by BMJ.

Arch Dis Child 2021;106:e38. doi:10.1136/archdischild-2017-313777corr1

(D) Check for updates 